\title{
A clinicopathological study of severe non-haemolytic anemia in age group of 0-18 years
}

\author{
Deka R. ${ }^{1}$, Hazarika P. ${ }^{2}$ \\ ${ }^{1}$ Dr. Rasadhar Deka, Associate Professor, ${ }^{2}$ Dr. Prabir Hazarika, Assistant Professor, both authors are affiliated with \\ Department of Pathology, JMCH, Jorhat, Assam, India.
}

Corresponding Author: Dr. Rasadhar Deka, Associate Professor, Department of Pathology, JMCH, Jorhat, Assam. E-mail: rasadhar.deka@gmail.com

\begin{abstract}
Introduction: Anaemia is typically defined as reduction in the haemoglobin concentration below certain value.The normal reference value of haemoglobin concentration defined by W.H.O. is $12.5 \mathrm{gm} / \mathrm{dl}$ for men and women. Evaluation of the causes of severe non haemolytic anaemia seems to be important as the various causes would respond to different treatment modalities. Methods: This was a hospital based prospective study that was carried out in a tertiary referral centre for one year, from January to December 2014. A total of fifty cases were subjected for thorough clinical examination and various investigations in order to provide information to evaluate their causes. Results: The maximum numbers of cases were reported in the age group of 3-6 years with male predominance. The maximum number of cases were diagnosed as Iron Deficiency Anaemia (22\%); followed by Acute Lymphoblastic Leukaemia (20\%), Acute Myeloblastic Leukaemia (16\%), Megaloblatic Anemia (16\%), Aplastic Anemia (10\%), Anemia of Chronic Disease (8\%). Conclusion: Evaluation of the causes of non haemolyticanemia seems to be important because different causes would respond to different treatment modalities; thus enabling the physician to plan out a successful therapeutic outline.
\end{abstract}

Key words: Clinicopathological, Severe anaemia, Non-haemolytic, Paediatric age, Haematological malignancies.

\section{Introduction}

Anemia, by modern simple definition, is a condition characterised by an abnormal reduction in body's total red cell mass [1]. As routine measurement of red cell mass is not always easy, anemia is typically defined as reduction in the haemoglobin concentration below certain value. The normal reference value of haemoglobin concentration defined by W.H.O. is $12.5 \mathrm{gm} / \mathrm{dl}$ for men and women [2]. Anemia is accordingly classified as-

$10.0-11.9 \mathrm{gm} / \mathrm{dl}$ - mild anemia

07.0-09.9gm/dl — moderate anemia

$<07.0 \mathrm{gm} / \mathrm{dl}$ — severe anemia [3]

Anemia in the group 0-18 years occupies a numerically important group of diseases which is leading a high morbidity and mortality [4]. Therefore, rapid and accurate diagnosis of paediatric anemia, including haematological malignancies have an increasing importance because an early and accurate diagnosis and treatment can reduce morbidity and can save many lives.

Manuscript received: $02^{\text {nd }}$ November 2018

Reviewed: $12^{\text {nd }}$ November 2018

Author Corrected: $17^{\text {th }}$ November 2018

Accepted for Publication: $23^{\text {th }}$ November 2018
If the easily diagnosable blood loss and hemolytic group of anemia are excluded, the nutritional deficiency is the leader of severe anemia. Thus, Iron Deficiency Anemia, Megaloblastic Anemia, Aplastic Anemia, the malignant diseases including leukaemia, lymphoma and anemia of chronic diseases are the distinct causes of non haemolyticanemia $[5,6,7]$. Keeping in mind all the facts delineated, the present study had been undertaken- to analyse the different causes of severe non haemolytic anemia among the children of 0-18 yrs with their relative incidence.

\section{Materials and Methods}

Study design: This is a hospital based prospective study. This study was conducted with 50 patients of age 0-18 years referred from the paediatric and medical units of a tertiary referral centre with clinical presentation of severe anemia.

\section{Aim and Objectives}

a) To evaluate the different causes and incidence of severe non haemolytic anemia among the age group $0-18$ years. 


\section{Original Research Article}

b) To make an analytical study of important clinical presentation and the haematological findings in different pattern of anemia.

Exclusion criteria: Patients with obvious blood loss, haemolytic group of anemia and patients with haemoglobin concentration of $7 \mathrm{gm} / \mathrm{dl}$ and above were excluded from this study. A provisional diagnosis based on clinical findings was recorded. Complete haematological examination was done including bone marrow and additional examinations (where necessary)Serum iron estimation, vitamin B12 \& folate estimation, serum billirubin, Hb electrophoresis, Pearl's stain cytological stain and BM trephine biopsy were included. FNAC \& histopathology for cervical and abdominal mass and radiological studies like Chest Xray, USG, CT scan etc. were done in selected cases. MGG stain was done for PBS and BM examination. MPO, PAS were used as cytochemical stain in BM aspiration.

\section{Results}

A total of fifty cases were subjected for thorough investigations. The most common physical finding apart from pallor was hepatomegaly and fever. Majority of the patients in the study were male in the age group of 3-6 years (28\%).

Table-1: Demographic distribution of cases

\begin{tabular}{|c|c|c|c|c|}
\hline Age in years & Male & Female & No of cases & Percentage \\
\hline 0 to 3 & 7 & 0 & 7 & 14.00 \\
\hline 3+ to 6 & 6 & 8 & 14 & 28.00 \\
\hline 6+ to 9 & 2 & 3 & 5 & 10.00 \\
\hline 9+ to 12 & 4 & 6 & 10 & 20.00 \\
\hline $12+$ to 15 & 3 & 2 & 5 & 10.00 \\
\hline 15+ to 18 & 4 & 5 & 9 & 18.00 \\
\hline Total & $\mathbf{2 6}$ & $\mathbf{2 4}$ & $\mathbf{5 0}$ & $\mathbf{1 0 0}$ \\
\hline
\end{tabular}

The majority of the cases were between the age group of 3 to 6 years, followed by the group between 9 to 12 years. Between 0-3 years of age no female cases were found. In this study male slightly outnumbered the female.

Table-2: Haemoglobin level of the cases.

\begin{tabular}{|c|c|c|}
\hline Hb level $(\mathbf{g m} / \mathbf{d l})$ & Number of cases & Percentage (\%) \\
\hline$<$ & 5 & 10 \\
\hline 3 to $<5$ & 16 & 32 \\
\hline 5 to $<7$ & 29 & 58 \\
\hline Total & $\mathbf{5 0}$ & $\mathbf{1 0 0}$ \\
\hline
\end{tabular}

Majority of the cases had haemoglobin level between 5 to $<7 \mathrm{gm} / \mathrm{dl}$ and 5 cases had haemoglobin level below $3 \mathrm{gm} / \mathrm{dl}$.

The causes of anemia under this study were found as -Iron deficiency anemia $-22 \%$ cases, Acute lymphoblastic leukaemia-20\%, Acute myeloblastic leukaemia-16\%, Megaloblastic anemia-16\%, Aplastic anemia-10\%, Anemia of chronic diseases-8\%, Juvenile CML-04\%, Lymphoma-04\% and Anemia of mixed deficiency - $02 \%$.

Table-3: Aetiological Pattern of Severe Non Hemolytic Anemia.

\begin{tabular}{|c|c|c|}
\hline Aetiology & No of Cases & Percentage (\%) \\
\hline IDA & 11 & 22.0 \\
\hline Megaloblastic Anemia & 08 & 16.0 \\
\hline Mixed Deficiency Anemia & 01 & 02.0 \\
\hline Aplastic Anemia & 05 & 10.0 \\
\hline Anemia of chronic diseases & 04 & 08.0 \\
\hline Acute LymphoblaticLeukemia & 10 & 20.0 \\
\hline Acute Myeloblastic Leukemia & 08 & 16.0 \\
\hline Juvenile Chronic Myelocytic Leukemia & 02 & 04.0 \\
\hline Lymphoma-NHL & 02 & 04.0 \\
\hline Total & $\mathbf{5 0}$ & $\mathbf{1 0 0 . 0}$ \\
\hline
\end{tabular}


Original Research Article

It was found that iron deficiency anemia was the most common cause of severe non haemolytic anemia followed by malignant causes (ALL).

Among the non malignant cases iron deficiency anemia was followed by megaloblastic anemia and aplastic anemia. And in malignant group acute lymphoblaticleukemia was the leader; followed by acute myeloblastic leukemia.

\section{Discussion}

In developed countries, a steady decline in prevalence of anemia in childhood age has been observed [8]. A study conducted in 2001-2002 in Nindura Block, Barabanki District, North India found severely anemic children in 3 subcentres as $2.73 \% ; 2.25 \%$ and $5.29 \%[9]$.

In another study, done by Deeksha Kapur et al (2001) found severe anemia as $7.8 \%$ among children. In this study, the severely anemic patients were found $8.5 \%$ within the specified age group.

A peak incidence of age distribution was found to be similar as compared to other studies like Harbans Lal et al and Sharma D K et al which showed 3-6 years as the commonest and second commonest age group respectively [10, 11].

Studies conducted worldwide, sex incidence varied from place to place. Hasanbegovic E et al found $49.33 \%$ male and $50.67 \%$ female. Similarly Rahim Fazlur et al found $66.27 \%$ male and $33.73 \%$ female which corresponds well to our study $[12,13]$.

Amongst the non malignant haematological disorders, nutritional anemia constituted $44 \%$ of which IDA is the most common (22\%), followed by megaloblastic anemia $(16 \%)$ and $2 \%$ cases had mixed deficiency causes.Similar observations were found by other authors.

White K. C et al (2005) found IDA as the major cause. In Amritsar, Harbans Lal et al studied 210 cases and found IDA as the major cause $(24.5 \%)[14,15]$.

Regarding Megaloblastic anemia, Gera et al found $7.8 \%$ and Choudhury et al found $27.1 \%$ and present study concordance with these two results $(16 \%)[16,17]$.

Incidence of Aplastic anemia were 18.7\% and 12.8\% in two separate studies done by Fazlur et al (2005) and S.P. Shah et al (1999) which is slightly higher than the present study [18]. This may be due to higher sample number and better facilities of BM evaluation.

Among the $44 \%$ of malignant causes of anemia, ALL is the most common (20\%) followed by AML (16\%) JCML (4\%) and NHL (4\%).

Fazlur et al reported $23.6 \%$ ALL, and $08.4 \%$ AML [19]. In a separate study by Vandana Jain et al ALL cases found in $27.2 \%$ and AML in $04 \%$ cases [20]. The higher incidence of AML in our study may be due to the higher age range.

In a comparative study with Fazlur $R$ et al found Megaloblastic anemia to be most common followed by Aplastic anemia. In our study IDA is found to be most common cause followed by Megaloblastic anemia among non malignant causes.

The difference of the incidence may be due to factor like geographic variation, bigger sample size and age variation. This study is conducted in an area with more BPL population where nutritional deficiency is more common.

More cases of Aplastic anemia could have been diagnosed had BM biopsy been undertaken.

Among the malignant causes slightly higher incidence in AML than the Fazlur R et al study is found. But similar findings with that of Dube et al is found.

And about JCML and NHL, the incidence is almost similar to the findings of the other workers. 
Original Research Article

Table-3: Showing correlation between provisional clinicaldiagnosis andconsistency with haematological diagnosis.

\begin{tabular}{|c|c|c|c|}
\hline $\begin{array}{l}\text { Hematological } \\
\text { Diagnosis } \\
\text { (No. of cases) }\end{array}$ & Provisional clinical Diagnosis (No of cases) & $\begin{array}{l}\text { Number of } \\
\text { consistent } \\
\text { cases }\end{array}$ & $\begin{array}{l}\text { Number of } \\
\text { inconsistent } \\
\text { cases }\end{array}$ \\
\hline $\operatorname{IDA}(11)$ & $\begin{array}{l}\text { Severe anemiawith hepatosplenomegaly-(2) } \\
\text { Nutritional anemia- (9) }\end{array}$ & 9 & 2 \\
\hline $\begin{array}{l}\text { Megaloblastic } \\
\text { Anemia(7) }\end{array}$ & $\begin{array}{l}\text { ?Viral encephalitis with severe anemia-(1); } \\
\text { Severe anemia with hepatosplenomegaly and bleeding } \\
\text { manifestation- (1) } \\
\text { Severe anemia with hepatosplenomegaly -(2); } \\
\text { Nutritional anemia- (3) }\end{array}$ & 3 & 4 \\
\hline Mixed Defi. Anemia (1) & Severe anemia. ? Nutritional with viral hepatitis-(1) & 1 & 0 \\
\hline $\begin{array}{l}\text { Anemia of Chronic } \\
\text { Disease (4) }\end{array}$ & $\begin{array}{l}\text { Anemia of chronic diseases- }(3) \\
\text { TB intestine with nutritional anemia(1) }\end{array}$ & 3 & 1 \\
\hline Aplastic Anemia(5) & $\begin{array}{l}\text { Severe anemia for evaluation- }(3) \\
\text { Anemia of nutritional origin- }(2)\end{array}$ & 3 & 2 \\
\hline $\operatorname{ALL}(10)$ & $\begin{array}{l}\text { Anemia with lymphadenopathy and } \\
\text { hepatosplenomegaly - (9) } \\
\text { Severe anemia with hepatomegaly - (1) }\end{array}$ & 9 & 1 \\
\hline AML (8) & $\begin{array}{l}\text { Anemiawith hepatosplenomegaly andbleeding } \\
\text { manifestation }\end{array}$ & 8 & 0 \\
\hline NHL (2) & $\begin{array}{l}\text { Anemia with generalized lymphadenopathy } \\
\text { andhepatosplenomegaly-(2) }\end{array}$ & 2 & 0 \\
\hline Juvenile CML (2) & $\begin{array}{l}\text { Severe anemiawithhepatosplenomegaly and } \\
\text { lymphadenopathy-(2) }\end{array}$ & 2 & 0 \\
\hline
\end{tabular}

Percentage of accuracy of provisional clinical diagnosis in the diagnosis of severe on haemolytic anemia by haematological analysis:

$\begin{array}{lll}\text { Total Anemia Cases (studied) } & : & 50 \\ \text { Consistent Results } & : & 40 \\ \text { Inconsistent Results } & : & 10 \\ \text { Percentage of Accuracy } & : & \mathbf{8 0 \%}\end{array}$
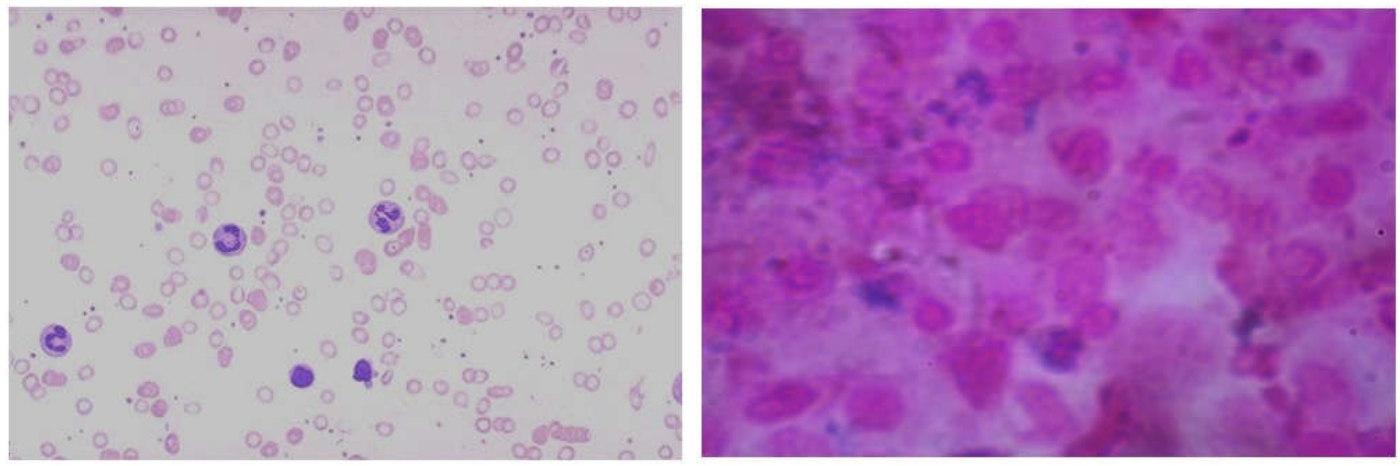

Fig-1A: IDA-PBS of a 6 Yrs Boy shows Severe Hypochromia with Poikilocytosis, Numerous Microcytic Cells with Adequate Platelets and White Blood Cells (Case 3). Fig 1B-PERL'S STAIN- Bone Marrow Smear of a 10 Yrs Boy showing Perls' Stain in a Diagnosed Case of JCML with Score '2' (normal iron particles, Case 49) 


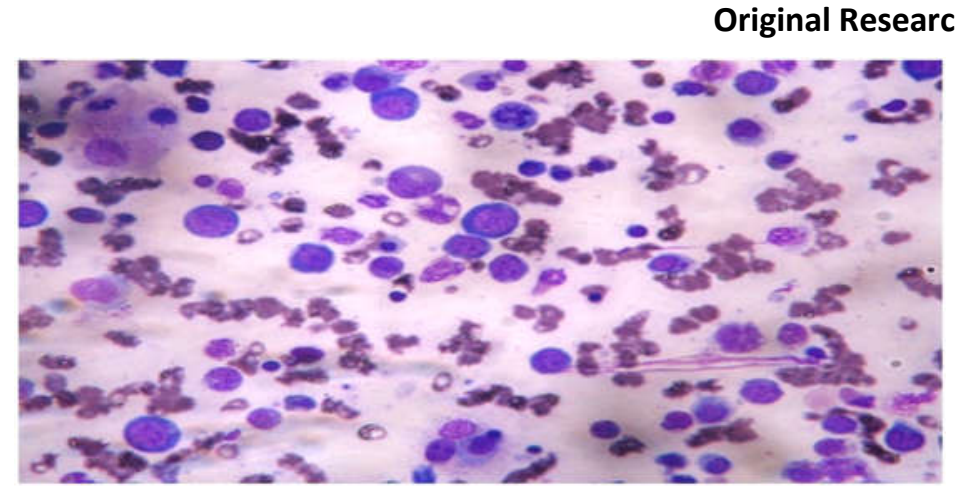

Fig-2: MA Bone Marrow Picture of a 14 Yrs Boy Shows Numerous Basophilic and Orthochromatic Megaloblasts with Open Lacy Chromatin (Case 30)

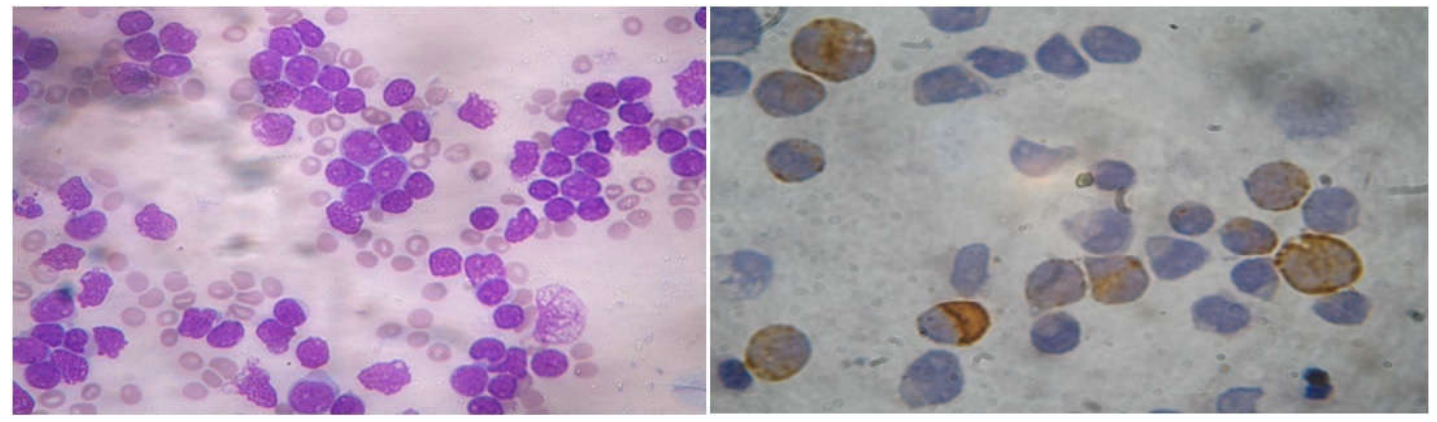

Fig-3A: AML M1 BM smear of an 11 Yrs Girl Shows Blast Cells with Large, Somewhat Irregular Nuclei with 1 or more Nucleoli. Cytoplasm Is Eccentric and Mostly Agranular. Very Few Cells Showed MPO Positivity (Case27). Fig 3BAML M2Bone Marrow Smear of a Patient Showing MPO Positivity (Case X1)

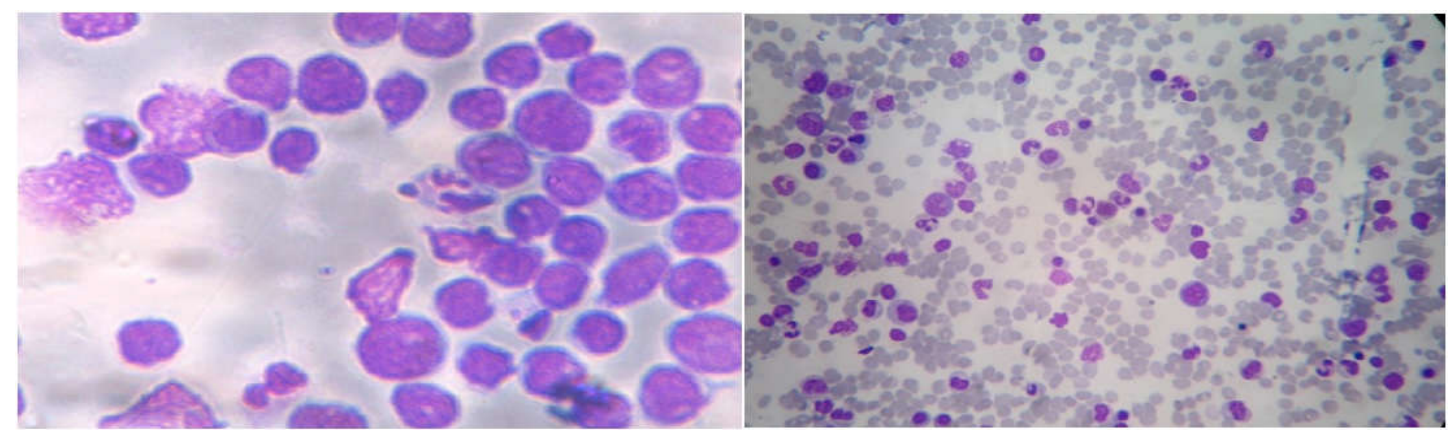

Fig-4A: ALL: (FAB-ALL L1) BM Picture of a 16 Yrs Male Shows Small, Uniform Blast Cells with Scanty Cytoplasm and Mostly Single Nucleolus. MPO was Negative (Case40). Fig 4B- JCML: Peripheral Blood Smear of a 10 Yrs Boy Shows Occasional Blast Forms, Atypical Agranular Bands And SegmentedNeutrophils (Case49).

\section{Conclusion}

Evaluation of the causes of non-haemolyticanemia seems to be important as the various causes would respond to different treatment modalities; thus enabling the physician to plan out a successful therapeutic outline that increase the patient's longevity.

The investigation of a case of severe non haemolyticanemia should include thorough clinical, haematological and related specific investigations. The causes of anemia varies from place to place depending on geographical variation, ethnicity, economy, food habits etc.
Authors' contributions: Rsasdhar Deka designed, searched data and literature and gave a critical view of manuscript writing. Prabir Hazarikagave critical view of manuscript writing. Both the authors' read and approved the final manuscript.

Acknowledgements: We acknowledge the support provided by the head of the department and the laboratory staffs of pathology department and also the clinician colleagues for sending the cases to us.

Findings: Nil; Conflict of Interest: None initiated Permission from IRB: Yes 


\section{Original Research Article}

\section{References}

1. Ed. Uthman, MD, Understanding anemia: University press of Mississipi 1998: 1-11

2. Fredrick M. Abrahaman: Anemia, Chronic: eMedicine: 2005: eMedicine.medscape.com

3. Deeksha Kapur, Kailash N. Agrawal, Sushma Sharma, Kusum Kela and Iqbal Kaur. Detecting iron deficiency anemia among children by implementing a screening program in an urban slum:Indian Paediatrics: 2002 Aug; 39 (7): 136-144, 671-6

4. Hussain Imam Hj Muhammad Ismail, Ng Hoong Phak, Terrence Thomas: Malaysia Paediatric Association: Why paediatric age limit must be raised to 18 years in Malaysia:Current Issue 2005; 1st edition

5. Frank Firkin, C. Chesterman, D Penington, B Rush: de Gruchy's Clinical hematology in Medical practice: $5^{\text {thedition: } 24}$

6. Louis A Kazal, JR. Prevention of iron deficiency in infants and toddlers: Am Fam Physician, 2002 Oct 1;66 (7): $1217-1225$

7. Dr. Saul Greenburg, MD, FRCP: Blood diseases and immune disorders. In: Caring for kids: Toronto; 2005

8. Margaret Lee. Anemia Acute: An article: American Academy of Paediatrics 2005

9. Awasthi S, et al. Anemia of under nutrition among preschool children in UP, India: Indian Paed: 2003:40 (10):985-990

10. Lal H, Manchanda SS, Khanna S, et al. Megaloblastic anaemia of infancy: a clinical and haematological study of 210 patients. Indian J Pediatr. 1972 Jul; 39 (294):217-26.

11. Sharma DK, Kalra K, Thapar RK, et al. Anemia in childhood. Indian Pediatr. 1970 Jul; 7 (7): 388-93.
12. Hasanbegović E, Bijedić V, Mehadzić S.Diagnostic value and cytomorphologic findings in bone marrow punctures in children with severe deficiency anemia. Med Arh. 2002;56 (3 Suppl 1) :33-5.

13. Fazlur Rahim et al: A spectrum of haematological disorders in children: Pak J Med Science :2005; Vol 21: 4: $433-436$

14. White KC. Anemia is a poor predictor of iron deficiency among toddlers in the United States: for heme the bell tolls. Pediatrics. 2005 Feb;115(2):31520.doi:10.1542/peds.2004-1488

15. Lal H, Manchanda SS, Khanna S, et al. Megaloblastic anaemia of infancy: a clinical and haematological study of 210 patients. Indian J Pediatrics: 1972 Jul;39(294):217-26.

16. Dr. Jagadish Chandra, MD: Vitamin $B_{12}$ and Folate deficiency: Megaloblastic anemia and Beyond: Indian Journal of Paediatrics: 2010 July;77: 795-799

17. Fazlur R et el: A spectrum of haematological disorders in children: Pak J Med Science: 2005, Vol 21: 4: $433-436$

18. SM Lewis; GJ Bain; I Bates: Dacie and Lewis Practical hematology: Basic Hematology Techniques: $9^{\text {th }}$ edition:20-21

19. John P Greer, MD; John Foerster, MD, FRCPC; John N Lukens, MD: Wintrobe's Clinical Hematology: Anemia: General Considerations: $11^{\text {th }}$ edition (Volume1): $960-961$

20. Vandana J, Dubey A. P, Gupta S K: Nutritional parameter in children with malignancy: Indian paediatrics 2003:40:976-984

\section{How to cite this article?}

Deka R., Hazarika P. A clinicopathological study of severe non-haemolytic anemia in age group of 0-18 years. Trop J Path Micro 2018; 4 (7): 539-544.doi:10.17511/jopm.2018.i07.10. 